Available online at: http://proceeding.rsfpress.com/index.php/ic-smart/index

Proceeding on International Conference of Science Management Art Research Technology

(IC-SMART)

Volume 1 Number 1 (2020): 26-32

\title{
Development Of Life-Based Curriculum Model Designs In The Global Era
}

\author{
Dedi Kuswandi ${ }^{1}$, Punaji Setyosari ${ }^{1}$, Hutkemri ${ }^{2}$, Nunung Suryati ${ }^{1}$, Tutut Chusniyah ${ }^{3}$, Risma \\ Chulashotud Diana ${ }^{1}$, Eko Saputra Nurdiansa ${ }^{1}$ \\ ${ }^{1}$ 1Educational Technology, State University of Malang, Indonesia; \\ ${ }^{2}$ Mathematics and Science Education, University of Malaya, Malaysia; \\ ${ }^{3}$ Psychology Education, State University of Malang, Indonesia; \\ Email address: dedi.kuswandi.fip@um.ac.id, Email address: punaji.setyosari.fip@um.ac.id, Email address: \\ hutkemri@um.edu.my, Email address: nunung_suryati@yahoo.com, Email address: \\ tututchusniah@yahoo.com,Email address: rismachulashotudddiana@gmail.com,Email \\ address:ekosaputranurdiansa21@gmail.com
}

\begin{abstract}
The curriculum as a learning planning document, which is then applied and implemented in a certain period, must always be updated so that it can keep up with the times, the development of science and technology, and the development of people's rapidly changing lives. No exception has been implemented by the Educational Technology Study Program (TEP), Faculty of Education (FIP) State the University of Malang. The Educational Technology Study Program has succeeded in implementing the curriculum renewal process by compiling a doctoral program curriculum (S3), which is based on the philosophy of life-based learning. By applying the research and development $(R \& D)$ method, this study aims to develop a life-based curriculum model design in the global era for doctoral programs. The research and development $(R \& D)$ method follows the ADDIE stages. The results of research and development are in the form of a model design that is described in chart form. The descriptions of the explanations for each component in the chart are systemic and systematic. Through the design of this curriculum model, it is hoped that it can become a guide for administrators of the educational technology (TEP) study program doctor so that during the course, the development of content knowledge and content pedagogy can be developed according to the life-based learning philosophy that characterizes the design of the curriculum model.
\end{abstract}

Keywords: curriculum model design, life-based learning philosophy, content knowledge, content pedagogy

\section{INTRODUCTION}

This is an open access article under the CC-BY-NC license

Education has a significant role in a country. Likewise, the Indonesian State has a noble goal in building a golden Indonesia, namely the intellectual life of the nation or society, and forming a noble character (Dewi 2019). Every effort is made by the government to achieve this noble goal. One of them is by making a policy of free learning and an independent campus. This policy is related to the policy of an Indonesian education figure, Mr. Ki Hadjar Dewantara (S. U . Risma Chulashotud Diana et.al , 2019). Then to implement the policy program is certainly not easy to implement new policies. 
Proceeding on International Conference of Science Management Art Research Technology (IC-SMART), Vol. 1 (1), 26-32

Development Of Life-Based Curriculum Model Designs In The Global Era

Dedi Kuswandi, Punaji Setyosari, Hutkemri, Nunung Suryati, Tutut Chusniyah, Risma Chulashotud Diana, Eko Saputra Nurdiansa

Many challenges become challenges to achieve this goal. Some of the current challenges are the industrial revolution 4.0, the pandemic period, and the new normal (Parikh et.al , 2020).

The industrial revolution era 4.0 has occurred and is now the world's attention. Moreover, the entry of the industrial evolution 4.0 was followed by a pandemic period. Ready or not, Indonesia still has to adapt to current developments (Julaeha , 2019). Preparing graduates who are qualified and able to compete in the global era is the outcome expected by Indonesian universities. So it is necessary to make policies that are able to make the program run at the same time can be implemented during a pandemic (Sofyan, 2019).

The Pandemic Period in Indonesia entered at the beginning of March 2020. This period was caused by the COVID-19 outbreak. This epidemic attacked various countries around the world (Akhmetshin et.al , 2019). Different sectors have been paralyzed, and some have even stopped entirely due to pandemic conditions among these sectors, namely the social sector, education, economy, health, and others. The affected communities are increasingly shocked by this situation. According to Mr. Hamid Muhammad, M.Sc., Ph.D. (Dirjen Pendidikan RI), Indonesia was late in adapting to this situation for about two months. Almost the entire world population is not ready for this period. Some activities had to be stopped. Activities carried out at home to avoid and prevent increased risk of impact. The government and all ranks continue to strive to get out of this problem (Zhang et.al ,2020).

Education is one of the sectors most affected during a pandemic. All activities are carried out at home. This change in habit is enough to make it difficult for the education component to adapt. Learning is carried out online without adequate preparation. Education data for 2020 showed 69 million children learn to use online, both formal and non-formal education. For this reason, proper learning will help maximize activities during the pandemic and new normal.

Life-based learning is learning that is developed to accommodate the knowledge and skills of students (Hambali, 2017). During the pandemic and new normal, life-based learning is needed to maximize the role of the family and society (Ali, 2019). For this reason, government efforts, together with families and communities, can be collaborated on the principles of life-based learning.

Government efforts to make educational advances continue, including by improving the quality of education. Of course, these efforts require cooperation from both academia and society (Diana, 2017). One of the steps to improve the quality of education is how to make learning innovations that are designed in such a way in the curriculum. The curriculum is the initial concept in starting quality learning and in accordance with the times. The curriculum is an essential document for learning planning at a particular time. The development of a curriculum model that is in accordance with the needs of the community and following the development of science and technology will help in the process of maximizing learning (Sutcliffe et.al, 2016).

This study will develop a life -based curriculum model design in the Educational Technology Study Program, Faculty of Education, State University of Malang. This study program has succeeded in implementing the curriculum renewal process for the Doctoral program based on the philosophy of life-based learning. The design of this curriculum model will be adapted to the global era. In developing the design of a new curriculum model, a comprehensive study and the vision and mission is required. Thus, the development of a curriculum design model will be based on the evaluation of the previous curriculum. Then at the time of the lecture, it is expected that content knowledge and content pedagogy can be developed according to the life-based learning philosophy, which is the hallmark of the curriculum model design. 
Proceeding on International Conference of Science Management Art Research Technology (IC-SMART), Vol. 1 (1), 26-32

\section{LITERATURE REVIEW}

Curriculum Model Development

The model or design in the curriculum is a component that determines the success of an educational process. Designing a curriculum is not an easy task but requires a comprehensive study in order to obtain results that can accommodate the demands and changes of the times. Creating a curriculum means compiling a curriculum model according to the school's mission and vision (Rusman et.al, 2017).

According to Mc Neill, curriculum design has five types: the social reconstruction curriculum, the humanities curriculum, the academic subject curriculum, and the technology curriculum. Many models can be used in curriculum development (Dai et.al, 2020). The selection of a curriculum development model is based not only on its strengths and benefits but also on the possibility of achieving optimal results and needs to be adjusted to the education system and educational processing system adopted and which educational concept model to use (Bovill etl.al, 2019). The curriculum development model in the education system and centralized management is different from the decentralized one. The curriculum development model, which is an academic subject, is different from the humanistic, technological, and social reconstruction curriculum (Alderson, 2020).

\section{Life-Based Learning}

Life-based learning is one of the pillars of the paradigm developed by UNESCO. This paradigm is related to the formation of the capabilities of students that are contained in life skills. If students have good life skills, they will be ready and handy in dealing with life problems. The pressure in the environment can be overcome proactively and creatively (Ayundasari, 2019).

In this era, there is uncertainty in priorities. Diversity appears so fast, followed by competition in various fields, including education. Individuals needed in this era are individuals who are ready to accept challenges and are able to answer problems based on needs. Likewise, individual skills to create ideas need to be developed to create something sustainably (Mintasih, 2018). Learning capability-based life, among which are (1) able to balance between knowledge, work, and study, (2) can conduct research, (3) can immediately capture life skills, (4) can associate the problem with the prowess of life is p incorporated (5) can resolve the issue in a new context (6) able to balance productivity and creativity (7) able to make adaptations between both direct and virtual environments. Life-based learning in the curriculum provides comfortable opportunities for learning in life, both directly and virtually. This learning is useful for increasing capabilities (Praherdhiono, 2018).

\section{Content Knowledge}

Content knowledge is initial knowledge related to subject matter that has not been studied (Csikos et.al, 2020). This material has been included in the curriculum that has been designed before learning is carried out. Knowledge in curriculum materials is consists of methods, theories, ideas, concepts, frameworks (Nind, 2020). The scientific method is also used to apply content knowledge in its implementation (Charalambous et.al, 2019). In everyday life, content knowledge is applied by students to focus on learning materials according to the curriculum.

\section{Content Pedagogy}

Pedagogy knowledge is an in-depth knowledge of theory and is balanced with practice (Gordani et.al, 2020). Implementing content pedagogy in learning life involves training following the approach that has been obtained. In pedagogy, knowledge also involves cognitive, affective, social, and theory 
Proceeding on International Conference of Science Management Art Research Technology (IC-SMART), Vol. 1 (1), 26-32

Development Of Life-Based Curriculum Model Designs In The Global Era

Dedi Kuswandi, Punaji Setyosari, Hutkemri, Nunung Suryati, Tutut Chusniyah, Risma Chulashotud Diana, Eko Saputra Nurdiansa

development (Livy et.al, 2019). The teacher's focus in the realm of learning is seen from how the use of learning methods, strategies, and practices to facilitate students in education (Khoza et.al, 2019). On the content pedagogy, teachers can assist students in finding even understand her identity (Torbeyns et.al, 2020). When students can understand themselves, they will be able to study well according to their abilities. Thus, students should understand their identity to be aware of the learning experience's goals.

\section{RESEARCH METHODOLOGY}

This study is research and development (R\&D). This research applied following ADDIE phases, namely analysis, design, development, implementation, and evaluation (Kuswandi, 2016). The research stages started from needs analysis, research design, developing a curriculum model, implementing a curriculum model design, and finally evaluating a curriculum model design product. This research was conducted at the Doctoral level (S3), majoring in Educational Technology, State University of Malang. Data collection techniques are carried out by observation and documentation. This curriculum development model refers to the Recursive, Reflective, Design, and Development (R2D2) model (Mustaji, 2010).

At the needs analysis stage, researchers distributed questionnaires to Doctoral (S3) students in Educational Technology. From this questionnaire, an evaluation of the curriculum that will be developed will be obtained. The questionnaire is distributed via a google form, which has been validated by experts.

The next stage is the research design stage. At this stage, development research was designed to develop a curriculum model design according to needs. At this stage, a workshop was held with a curriculum expert professor in Indonesia.

After conducting the research design, the next step is to develop a curriculum development model. Developing design curriculum models are made according to the workshop results with the research team, curriculum development team (university and educational technology program).

After developing a curriculum model design, the curriculum model design's implementation is carried out by strengthening it, several trials, and validations. Implementation is carried out by the research team and curriculum developers at both the departmental and university levels. Expert lecturers carried out the validation of the curriculum model design at the professors' level both within the university and by inviting from other universities.

The final stage is the evaluation of curriculum development research. An opinion poll test is carried out and finalizes the curriculum model design for the Doctoral (S3) Educational Technology study program.

\section{FINDING AND DISCUSSION}

This study develops a curriculum model design for the Doctor of Educational Technology program. The research was carried out to update an existing curriculum. This is done to adapt to the development of science and technology and the needs of the community. Life-based learning philosophy is the basis of the curriculum design of the doctor program Education Technology at the State University of Malang. 


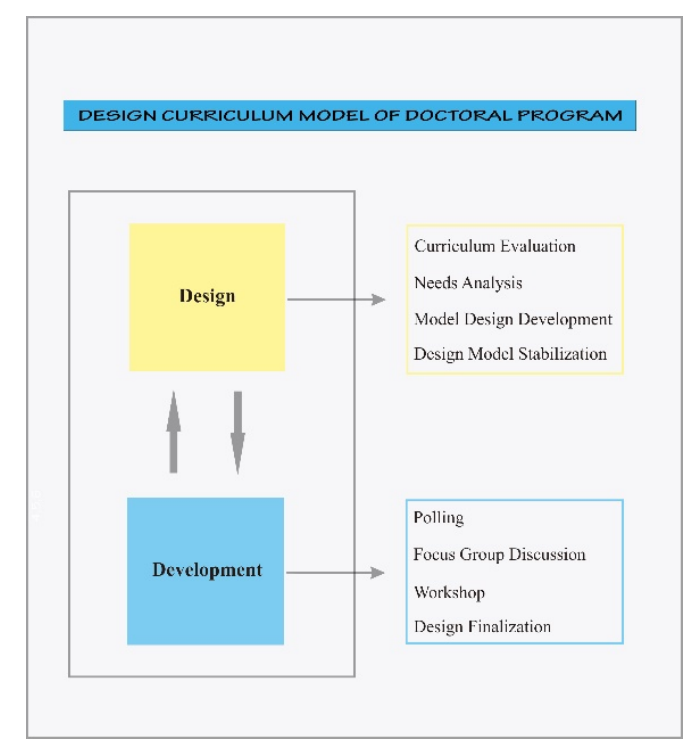

Figure 1. Curriculum Model Design of Educational Technology Doctoral Program State University of Malang

In this design, two essential stages are carried out, namely design and development. The picture above can be seen as an overview of the curriculum design model that the researcher developed. Then this design will be explained at every stage of its descriptive.

Several research activities are carried out at the design stage, including curriculum evaluation, needs analysis, model development, and strengthening curriculum model design.

First, curriculum evaluation activities are carried out by distributing curriculum evaluation questionnaires in google form to students of the educational technology doctoral program. Second, needs analysis is carried out by looking at the results of curriculum evaluation data in previous activities. This activity is carried out by the research team and curriculum development team. After needs analysis is carried out, the description of the curriculum model to be developed will be adjusted according to the needs. Third, the development of a curriculum model is carried out by the team by conducting FGDs, workshops, and workshops. In addition, several trials and validations were conducted by curriculum experts. Researchers involve professors from inside and outside the university to carry out development activities. The last activity is strengthening the design of the curriculum model.

Then at the development stage, several more in-depth activities were carried out in making a curriculum design model for the educational technology doctoral program. First, the opinion poll was carried out by 12 Indonesian education experts online. In this activity, an overview of the indicators for the formulation of curriculum design development was produced. Second, Focus Group Discussion (FGD) activities are carried out as a follow-up to previous activities. Researchers and national education experts conduct fGDs in order to design a curriculum model design. Third, the workshop activities were carried out with almost the same objectives as the previous activities. But this year, it is done only from the research team and development team. Fourth, the finalization of curriculum model design development activities is carried out by the entire research team and parties involved in this research. 
Proceeding on International Conference of Science Management Art Research Technology (IC-SMART), Vol. 1 (1), 26-32

Development Of Life-Based Curriculum Model Designs In The Global Era

Dedi Kuswandi, Punaji Setyosari, Hutkemri, Nunung Suryati, Tutut Chusniyah, Risma Chulashotud Diana, Eko Saputra Nurdiansa

This research is expected to become a guideline for the implementation of a doctoral program in educational technology. Then in the implementation of the curriculum in lectures, it is able to develop content knowledge and content pedagogy that is adjusted to the philosophy of life-based learning. This is also what characterizes the development of curricula that were studied with the previous curriculum.

\section{CONCLUSION AND FURTHER RESEARCH}

Conclusions from curriculum development research are needed to improve learning. This study develops a new curriculum model design in the educational technology doctoral program at the State University of Malang based on life-based learning philosophy. The results of this development research will serve as a learning guide for the S3 Educational Technology program for the next lecture. The development of a curriculum model design is carried out according to the previous curriculum evaluation. The implementation of the curriculum model design in courses is expected to develop student content knowledge and consistent pedagogy.

\section{REFERENCES}

Akhmetshin, E. M., Mueller, J. E., Yumashev, A. V., Kozachek, A. V., Prikhodko, A. N., \& Safonova, E. E. (2019). Acquisition of entrepreneurial skills and competences: Curriculum development and evaluation for higher education. Journal of Entrepreneurship Education, 22(1), 1-12.

Alderson, P. (2020). Powerful knowledge and the curriculum: Contradictions and dichotomies. British Educational Research Journal, 46(1), 26-43.

Ali, S. S. (2019). Problem Based Learning: A Student-Centered Approach. English language teaching, 12(5), 73-78.

Ayundasari, L. (2019). Urgensi Pengembangan Model Belajar Sejarah Berbasis Eco-Histourism dalam Rangka Optimalisasi Potensi Lingkungan dan Sejarah di Wilayah Amstirdam. Sejarah dan Budaya: Jurnal Sejarah, Budaya, dan Pengajarannya, 13(1), 1-11.

Bovill, C., \& Woolmer, C. (2019). How conceptualisations of curriculum in higher education influence student-staff co-creation in and of the curriculum. Higher Education, 78(3), 407-422.

Charalambous, C. Y., Hill, H. C., Chin, M. J., \& McGinn, D. (2019). Mathematical content knowledge and knowledge for teaching: exploring their distinguishability and contribution to student learning. Journal of Mathematics Teacher Education, 1-35.

Csíkos, C., \& Szitányi, J. (2020). Teachers' pedagogical content knowledge in teaching word problem solving strategies. ZDM, 52(1), 165-178.

Dai, D., Sakaridis, C., Hecker, S., \& Van Gool, L. (2020). Curriculum model adaptation with synthetic and real data for semantic foggy scene understanding. International Journal of Computer Vision, 128(5), 1182-1204.

Dewi, P. (2020). SOSIALISASI PENGEMBANGAN KURIKULUM "LEARNING ACTIVITIES”. VALUES: Jurnal Pengabdian kepada Masyarakat, 2(1), 63-69.

Diana, R. C. (2013). Ar Qurani (Al Ibrah Qurani): Upaya Internalisasi Nilai-Nilai Qurani Pada Anak Muslim Indonesia Berbasis Modul Kisah Teladan Al Qur'an. Jurnal Pendidikan Nasional, 2(3).

Diana, R. C., Kuswandi, D., \& Ulfa, S. (2019). Konsep Pembelajaran TRINGO pada Mata Kuliah Model Pengembangan Kurikulum. Jurnal Kajian Teknologi Pendidikan, 2(2), 90-95.

Gordani, Y., \& Khajavi, Y. (2020). The impacts of multi-modal PowerPoint presentation on the EFL students' content knowledge attainment and retention over time. Education and Information Technologies, 25(1), 403-417.

Hambali, M. (2019). PEMBELAJARAN BERBASIS KEHIDUPAN: KONSEP DAN IMPLEMENTASINYA DALAM PEMBELAJARAN BAHASA INDONESIA. Waskita: Jurnal Pendidikan Nilai dan Pembangunan Karakter, 1(1), 129-136. 
Julaeha, S. (2019). Problematika Kurikulum Dan Pembelajaran Pendidikan Karakter. Jurnal Penelitian Pendidikan Islam, [SL], 7(2), 157-182.

Khoza, S. B., \& Biyela, A. T. (2019). Decolonising technological pedagogical content knowledge of first year mathematics students. Education and Information Technologies, 1-15.

Kuswandi, D. (2016). Developing Connectivism Learning In Social Learning.

Livy, S., Herbert, S., \& Vale, C. (2019). Developing primary pre-service teachers' mathematical content knowledge: Opportunities and influences. Mathematics Education Research Journal, 31(3), 279-299.

Mintasih, D. (2018). Mengembangkan literasi informasi melalui belajar berbasis kehidupan terintegrasi PBL untuk menyiapkan calon pendidik dalam menghadapi era revolusi industri 4.0. ELEMENTARY: Islamic Teacher Journal, 6(2), 271-290.

Mustaji, M. (2010). Pengembangan Model Pembelajaran Berbasis Masalah Dengan Pola Belajar Kolaborasi (Model PBMPK). Jurnal Pendidikan dan Pembelajaran Universitas Negeri Malang, 17(2), 187-200.

Nind, M. (2020). A new application for the concept of pedagogical content knowledge: teaching advanced social science research methods. Oxford Review of Education, 46(2), 185-201.

Parikh, S. V., Almaani, S., Brodsky, S., \& Rovin, B. H. (2020). Update on Lupus Nephritis: Core Curriculum 2020. American Journal of Kidney Diseases.

Praherdhiono, H., Adi, E. P., \& Prihatmoko, Y. (2018). Konstruksi demokrasi belajar berbasis kehidupan pada implementasi LMS dan MOOC.Edcomtech Jurnal Kajian Teknologi Pendidikan, 3(1), 21-28.

Rusman, R., \& Rohman, A. (2017). Development of Training Curriculum in Improving CommunityBased Geological Hazard Mitigation Competency. Mimbar: Jurnal Sosial dan Pembangunan, 33(2), 416-425.

Sofyan, F. A. (2019). Implementasi HOTS pada kurikulum 2013. INVENTA: Jurnal Pendidikan Guru Sekolah Dasar, 3(1), 1-9.

Sutcliffe, N., Chan, S. S., \& Nakayama, M. (2020). A competency based MSIS curriculum. Journal of Information Systems Education, 16(3), 8.

Torbeyns, J., Verbruggen, S., \& Depaepe, F. (2020). Pedagogical content knowledge in preservice preschool teachers and its association with opportunities to learn during teacher training. ZDM, $1-12$.

Zhang, W., Wang, Y., Yang, L., \& Wang, C. (2020). Suspending classes without stopping learning: China's education emergency management policy in the COVID-19 Outbreak. 